\title{
From the worm's point of view. I: Environmental settings of benthic ecosystems in Arctic fjord (Hornsund, Spitsbergen)
}

\author{
Anna Drewnik ${ }^{1}$ - Jan Marcin Węsławski ${ }^{1}$ - Maria Włodarska-Kowalczuk ${ }^{1}$. \\ Magdalena Lącka ${ }^{1}$ Agnieszka Promińska ${ }^{1} \cdot$ Agata Zaborska $^{1} \cdot$ Marta Gluchowska $^{1}$
}

Received: 19 December 2014/Revised: 15 December 2015/Accepted: 15 December 2015/Published online: 27 January 2016

(C) The Author(s) 2016. This article is published with open access at Springerlink.com

\begin{abstract}
As a consequence of ongoing climate warming, nearly all tidal glaciers in Arctic are retreating; hence, the seascape of glacial fjords is changing in many aspects. We took the example of Hornsund, the well-studied Svalbard fjord, with over 30 years of almost continuous observations of marine system. Recent data were collected during summer oceanographic surveys between 2001 and 2013 and compared with archival data from 1980s. As most of the phenomena connected with the warming happen at the sea surface (ice, wind, waves, surface currents, brackish water), we were interested, how the presumably stable, near-bottom waters in fjords behave, what are the environmental changes that are experienced directly by the worms living in the sediment. We have found that both the inner fjord basins (usually regarded as stable) and the outer fjord parts (exposed to the direct influence of shelf waters) has changed. Warming was documented in the inner basins, while cooling and warming episodes were recorded in the outer parts of the fjord. We demonstrate that following the increase melting and retreat of the glaciers, the area of shallows increased, salinity decreased and temperature increased-partly due to the advection of Atlantic waters from the shelf. Observed changes are in accordance with the model of arctic fjords evolution towards boreal ones associated with increased organic matter turnover. The observed changes are most likely typical for all cold water, glaciated fjords that are exposed to climate warming.
\end{abstract}

Anna Drewnik

drewnik.anna@gmail.com

1 Institute of Oceanology, Polish Academy of Sciences, Powstancow Warszawy 55, 81-712 Sopot, Poland
Keywords Arctic - Fjord - Benthos - Environmental conditions $\cdot$ Climate change $\cdot$ Near-bottom waters

\section{Introduction}

Fjord oceanography was the focus of oceanographic research during the NATO Advance Science Workshop in 1980 and was later presented in baseline handbooks by Syvitski et al. (1987). The basic paradigm of boreal and Arctic fjords was that they represented a particular case of estuarine circulation, with isolated basins and presence of residual near-bottom water in the innermost basin (Pearson 1980). According to Pearson (1980), the functioning of fjords was controlled by hydrodynamic forcing, where hydrodynamic input was diminished from the ocean towards the inner fjord, resulting in carbon limitation in the outer fjord (rich benthos, intensive carbon cycling) and nutrients sink in the inner fjord basin (poor benthos, intensive pelagic-benthic sink). Long-term multidisciplinary studies of places with such specific characteristics are of great value, especially in areas most impacted by global warming like the European Arctic (ACIA 2005).

Contrary to the shelf and open bays, there are not many complex oceanographical studies in Arctic fjords. Some well-studied fjords in Arctic that may serve as a comparison with the presented site are Kongsfjord, Van Mijen and Isfjord on Spitsbergen (Hop et al. 2002; Svendsen et al. 2002; Renaud et al. 2007), Disco Bay and Young Sound on Greenland (Schmid and Piepenburg 1993; Rysgaard and Glud 2007), and Murres Inlet on Alaska (Powell and Molnia 1989). The marine system of Hornsund, the southernmost of the Spitsbergen fjords, has been investigated since the mid-1970s (Siwecki and Swerpel 1979; Urbański et al. 1980; Swerpel 1985; Görlich et al. 1987; 
Swerpel and Węsławski 1989). The summer studies have continued since then and were recently conducted with more modern equipment (undulating CTD, long continuous profiles). In our studies, we attempted to compare old and new abiotic data from the Hornsund fjord, with a special focus on the situation in the near-bottom layer, as it is of vital importance for the benthos-the long-living part of the ecosystem. Hornsund is rich in benthic organisms with over 500 species of macrofauna recorded in the soft bottom only (Kędra et al. 2010a; Włodarska-Kowalczuk et al. 2012), and a biomass ranging up to $100 \mathrm{~g}$ wet weight $\mathrm{m}^{-2}$ (Görlich et al. 1987).

Since benthic organisms have longer life cycles and more limited dispersion ability than planktonic communities, they better integrate hydrographic processes over the years and are believed to serve as better indicators of longterm environmental changes (Warwick 1993; Kröncke 1995; Renaud et al. 2008). The abiotic factors ascribed to have the greatest impact on benthic fauna persistence and distribution are temperature, salinity, oxygen concentration, sediment texture, sedimentation rates as well as trophic conditions indicated by organic carbon and, indirectly, chlorophyll $a$ concentrations in sediments (Snelgrove 2001; Gray 2002; McArthur et al. 2010). Factors that can either directly influence benthic communities or act as the strong proxies for other variables are, among others, depth and seabed slope-a geomorphology feature that describe structural complexity of the seabed (McArthur et al. 2010). One of the strongest impacts on benthic communities inhabiting glacial fjords is produced by glacial outflows loaded with large amount of mineral material (Görlich et al. 1987; Dale et al. 1989; Wlodarska-Kowalczuk and Pearson 2004).

As the phenomena of glacial retreat are widespread nowadays in the Arctic (Hagen et al. 2003; Błaszczyk et al. 2009), the glacial fjords benthos is experiencing major environmental change. Such changes took place in recent history as glaciologists report complete or almost complete disappearance of Svalbard glaciers during last climate optimum (Koerner and Fisher 2002), glacial advance during Little Ice Age in fourteenth to nineteenth centuries (Dowdeswell 1995; Pawłowska et al. unpublished data) and periods of warming in twentieth and twenty-first centuries. Additional pressure comes with the increased Atlantic water inflow towards west Spitsbergen fjords (Pavlov et al. 2013). Strong salinity gradient that separates brackish surface waters from lower part of the water column in glacial fjords like Hornsund (Svendsen et al. 2002; Łacka and Zajączkowski 2015) may result in different response of surface and near-bottom waters to such external forcing. This fact, together with the key role that seabed plays for benthic communities and in biogeochemical processes, highlights the importance of conducting complex monitoring studies. Broad environmental data collection near the seabed is not common, with only a few recent examples, such as Glover et al. (2010) from Fram Strait and Hoelemann et al. (2011) from Laptev Sea, both of which present a marked increase in near-bottom temperatures over last years.

The purpose of our study is to present environmental conditions prevailing at the bottom of the Hornsund fjord and re-discuss the environmental processes that affect benthic communities in fjords. This is the first study to address this issue with such a numerous amount of abiotic parameters measured in Hornsund. We present data on deeper soft bottom sublittoral $(<50 \mathrm{~m})$, with no data from shallows and hard substrata. With the use of statistical testing and GIS tools (geographic information systems), we aim to illustrate and analyse conditions that long-living benthic fauna encounters at the bottom of the sea. The following questions were the focus of this study: what are the local environmental barriers near the seabed? Do the separate fjord basins change in the same way or differently? How stable are benthic environmental conditions in the fjord? All of these questions are discussed on the background of historical data from 1980s. The second paper shows benthos species occurrence and its spread as projected with the Species Distribution Modelling statistical tool.

\section{Materials and methods}

\section{Study area}

The Hornsund fjord is under the influence of two distinct water masses: warm and saline Atlantic Water transported by the West Spitsbergen Current from the Norwegian Sea and cold, less-saline Arctic-type Water carried by the Sørkapp Current from the northeast Barents Sea (Piechura et al. 2001; Cottier et al. 2005). Both water masses can easily penetrate the fjord area because Hornsund does not have a sill at the entrance. However, several topographic shallows of the seafloor occur throughout the fjord, separating individual basins (Rudowski and Marsz 1996). All of the water formations found in the fjord depend on Atlantic, Arctic and glacier waters mixing and vary seasonally (Svendsen et al. 2002; Cottier et al. 2005) as well as interannually (Walczowski and Piechura 2006). Hornsund, like other fjords of western Spitsbergen, belongs to broad fjords, which means that rotational effects will modify the main water flow. Thus, water entering the basin will tend to inflow along southern coast and outflow along northern coast of the fjord (Cottier et al. 2010). Water of Atlantic origin (modified by mixing with Arctic Water) is usually observed as a bottom inflow. Its distribution and range 
differ from summer to summer and is limited by the shallow sills while entering the inner basins. (Promińska et al. unpublished data). As much as $70 \%$ of the Hornsund's catchment area is covered with glaciers, with thirteen of them directly entering the fjord (Błaszczyk et al. 2013). It has been estimated that tidewater glaciers in Hornsund retreat faster $\left(\sim 70 \mathrm{ma}^{-1}\right.$ on average $)$ than elsewhere on Svalbard $\left(\sim 45 \mathrm{ma}^{-1}\right.$ on average), most likely due to local topographic conditions, climate and Atlantic water fluxes. Hence, the Hornsund region is believed to be more vulnerable to climatic-oceanic system change than the rest of the archipelago (Błaszczyk et al. 2013).

\section{Sampling and laboratory analysis}

Sampling was performed in the Hornsund fjord (Spitsbergen) during routine summer R/V OCEANIA cruises of the Institute of Oceanology Polish Academy of Sciences between 2001 and 2013. Surface sediments were collected at 27 stations in 2012 (Fig. 1). Sediment samples for granulometric analysis, as well as organic carbon content and chlorophyll $a$ concentration, were collected from a box-corer with a 2-cm-wide plastic syringe (upper 5, 2 and $2 \mathrm{~cm}$, respectively). Samples were frozen onboard at the temperature of $-80{ }^{\circ} \mathrm{C}$ and transported to the laboratory. Then sediments were freeze-dried in vacuum at the temperature of $-70{ }^{\circ} \mathrm{C}$ and homogenized precisely by an Agate mortar and pestle. Grain size $(<2 \mathrm{~mm})$ analyses were performed using a Malvern Mastersizer 2000 laser particle analyzer and presented as volume percent. Mean grain size was calculated in the program GRADISTAT 8.0 by the geometric method of moments (Blott and Pye 2001). Organic carbon content $\left(\mathrm{C}_{\text {org }}\right)$ in the sediment was measured with the use of an Elemental Analyzer Flash EA 1112 Series and the Isotopic Ratio Mass Spectrometer IRMS Delta V Advantage (Thermo Electron Corp., Germany). Dry and homogenous sediment samples were weighed (4 mg) and acidified with $2 \mathrm{M} \mathrm{HCl}$ (Hedges and
Stern 1984; Chang et al. 1991). The reference gases $\left(\mathrm{N}_{2}\right.$ and $\mathrm{CO}_{2}$ ) were calibrated against IAEA standards. Quality control of the organic carbon concentrations measurements was conducted with standard materials supplied by the Thermo Electron Corp. Accuracy and precision resulting from the method used were satisfactory (average recovery $99.1 \pm 2.0 \%)$. Chlorophyll $a(\mathrm{Chl} a)$ concentration in the sediment samples was measured with fluorometric method (Evans et al. 1987) with use of Perkin Elmer LS55 Fluorescence Spectrometer. Pigment from freeze-dried sediments was extracted in $90 \%$ acetone for $24 \mathrm{~h}$ at $4{ }^{\circ} \mathrm{C}$. Emission at $671 \mathrm{~nm}$ excited at $431 \mathrm{~nm}$ was measured before and after sample acidification with $1 \mathrm{M} \mathrm{HCl}$ and used to calculate the $\mathrm{Chl} a$ concentration according to the method described by Evans and O'Reilly (1983).

Sedimentation rates were assessed with sediment traps (double cylindrical, $72 \mathrm{~mm}$ diameter, $0.46 \mathrm{~m} \mathrm{long}$ ), exposed for $10 \mathrm{~h}$ at 17 locations in 2012 and 2013 (Fig. 1). Samples were vacuum-filtered onto pre-weighted MN GF5 filters $(0.4 \mu \mathrm{m}$ pore size $)$ and rinsed with distilled water. The filters were dried at $60{ }^{\circ} \mathrm{C}$ for $24 \mathrm{~h}$, weighed to determine sediment dry mass and combusted at $450{ }^{\circ} \mathrm{C}$ for $24 \mathrm{~h}$. The organic matter amount was calculated as a weight loss in combustion. This value was subtracted from the total mass in order to obtain the amount of settled mineral matter.

Long-term measurements of water temperature and salinity along fjord axis were performed during 2001-2012 period. Data were collected with an SBE 49 probe, profiling at $16 \mathrm{~Hz}$, with an increased accuracy of $0.0003 \mathrm{mS} \mathrm{cm}^{-1}, 0.002{ }^{\circ} \mathrm{C}$, and $1 \%$ of the full-scale range, for conductivity, temperature, and pressure, respectively. The data were processed and averaged every $1 \mathrm{~dB}$ in the SBE Data Processing program using standard procedures. Additional point data were collected in 2012. The CTD probe (SBE 911plus, Seabird Electronics Inc., USA) was lowered vertically from the surface to a few meters above the bottom at 27 stations distributed throughout the fjord (Fig. 1). Near-bottom measurements
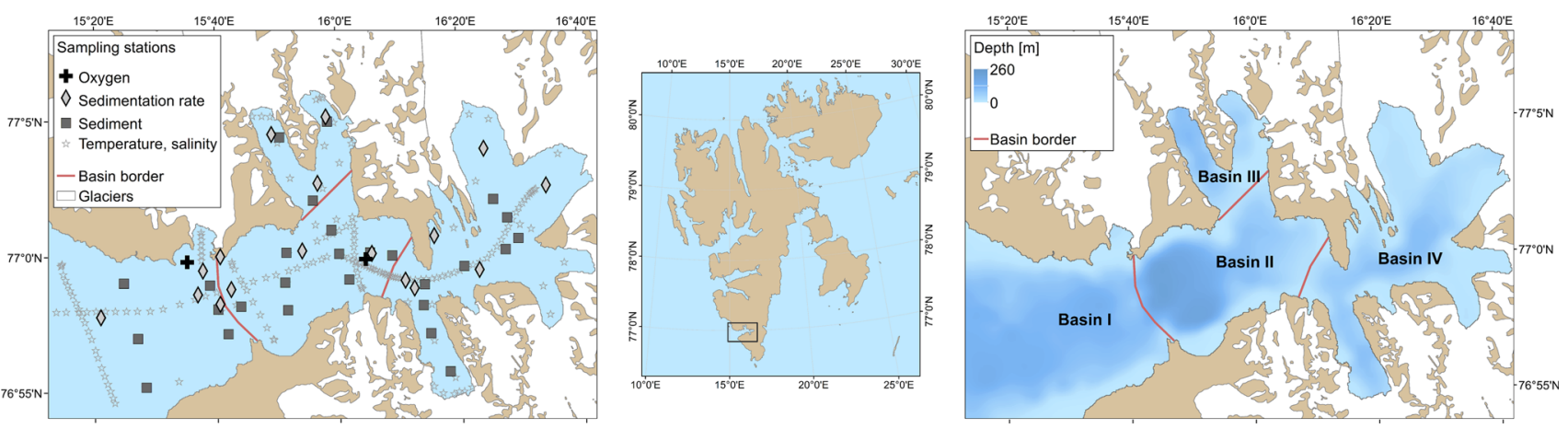

Fig. 1 Study area-Hornsund fjord (Svalbard Archipelago, Arctic). Location of sampling stations and individual fjord basins (borders set at topographic shallows of the seafloor) 
were analyzed separately to present the conditions prevailing near the seabed.

Oxygen concentration and saturation in the bottom waters were measured at two sampling stations during the 2013 summer season (Fig. 1). Locations were repeated after Urbański et al. (1980) in order to monitor oxygen values after a prolonged period. IntelliCAL ${ }^{\mathrm{TM}}$ LDO101 luminescent/ optical dissolved oxygen (LDO) probe $(\mathrm{HACH})$ was used.

The water depth was measured simultaneously with other environmental variables at each sampling station (Echotrac MK III $12 \mathrm{kHz}$, Odom Hydrographic Systems). Additionally, the new detailed bathymetric charts (Moskalik et al. 2013) were compared with older sea charts used for navigation.

\section{Data visualization and GIS analysis}

In order to visualize the area of interest and the distribution of measured parameters throughout the fjord, GIS analyses were performed with the use of ArcGIS 10.1 software. Upto-date coastline and glaciers range were digitized from Landsat 8 satellite images of the Hornsund fjord from year 2013.

Mineral sedimentation rate values, $\mathrm{C}_{\text {org }}$ content and $\mathrm{Chl}$ $a$ concentration in the sediments were visualized as a graduate symbol point layer due to number of points not high enough for interpolation. The mean grain size of the sediment was categorized based on the Wentworth (1922) scale and displayed as a point layer with the use of graduated colors symbology.

Other environmental variables were visualized as continuous layers. The interpolation method was chosen depending on sampling design and character of each factor as to minimize the extrapolation error: inverse distance weighted (IDW) for bathymetry and Spline with Barrier in case of bottom water temperature and salinity. Depth layer was later used to calculate slope of a seabed (slope tool). Bathymetry was additionally reclassified with the threshold set every $50 \mathrm{~m}$. Output cell size of created rasters was $50 \mathrm{~m}$.

Additional continuous layer was created in order to illustrate long-term variability of near-bottom water temperature and salinity across fjord axis. Mean values of temperature and salinity in basins were calculated for each year. Results were given coordinates, displayed as point data in ArcGIS 10.1 and interpolated using Spline method.

In order to illustrate areas of uniform environmental conditions at the bottom of Hornsund fjord, we performed Grouping Analysis on data collected in 2012. Values of environmental variables were assigned to point data representing sampling locations. This tool performs a classification procedure that looks for a solution where all the features within each group are as similar as possible, and all the groups themselves are as different as possible. Feature similarity is based on the set of attributes (here values of analysed parameters) assigned to points (sampling locations). All GIS analyses were performed according to methods described by ArcGIS Help Library (http://resources.arcgis.com/).

\section{Statistical analysis}

In order to verify whether environmental conditions at the seabed differ across the fjord, we divided the fjord area into four separate basins (I, II, III and IV) based on topographic shallows of the seafloor (Fig. 1). We quantified basic descriptive statistics and tested whether there were statistically significant differences between fjord basins with regard to the following parameters: $\mathrm{C}_{\text {org }}$ content and $\mathrm{Chl}$ $a$ concentration in sediments-proxies for trophic conditions, mean grain size of sediments, mineral matter sedimentation rates, depth, slope, temperature and salinity of near-bottom water. We used nonparametric Kruskal-Wallis and post hoc Dunn tests. All the analyses were performed using STATISTICA 10.0 (StatSoft Inc. 2011). Statistical significance was accepted at $p<0.05$.

\section{Results}

Statistical testing of differences between four individual fjord basins with regard to analysed variables revealed the smallest distinction between Basins III and IV (only one variable differed significantly), as well as Basins I and II (only two variables differed significantly). Results of post hoc testing can be found in Table 1. Hornsund fjord was homogenous in terms of trophic conditions. Statistical testing revealed no significant differences between fjord basins with regard to $\mathrm{C}_{\text {org }}$ content in sediments $\left(\mathrm{H}_{(3, N=27)}=0.50, p=0.918\right)$. Concentration of Chl $a$ in the sediments differed significantly only between Basins III and IV $\left(\mathrm{H}_{(3, N=27)}=7.98, \quad p=0.046\right.$, Dunn's test: $p=0.049$ ). Nonetheless, higher mean values of both parameters were observed at the fjord entrance and in the most inner basin (Fig. 2). Hornsund seafloor was dominated by fine-grained sediments (Fig. 3). Post hoc testing revealed a significant difference only between Basins IV and I (Dunn's test: $p=0.015$ ) as patches of several types of sediments were noted at the fjord entrance. Mineral matter sedimentation rates differed statistically only between Basins II and III $\left(\mathrm{H}_{(3, N=17)}=7.99, p=0.046\right.$, Dunn's test: $p=0.034)$. Nonetheless, higher mean rates were observed in the inner basins than outer ones, with maximum in Basin III (Fig. 4). The highest values of slope were observed along the coastline at the entrance to Basin II (Fig. 5a). Statistical analysis showed significant 
Table 1 Differences between four individual Hornsund fjord basins with regard to selected environmental parameters

\begin{tabular}{|c|c|c|c|c|c|c|}
\hline \multirow[t]{2}{*}{ Environmental variable } & \multicolumn{6}{|l|}{ BASINS } \\
\hline & I versus II & I versus III & I versus IV & II versus III & II versus IV & III versus IV \\
\hline $\mathrm{C}_{\text {org }}$ content in sediments & - & - & - & - & - & - \\
\hline Chlorophyll $a$ concentration in sediments & - & - & - & - & - & + \\
\hline Mean grain size of sediments & - & - & + & - & - & - \\
\hline Mineral matter sedimentation rates & - & - & - & + & - & - \\
\hline Slope of the seabed & - & - & + & - & + & - \\
\hline Depth & + & + & + & + & + & - \\
\hline Near-bottom water temperature & + & + & + & + & + & - \\
\hline Near-bottom water salinity & - & + & + & + & + & - \\
\hline
\end{tabular}

+: statistically significant difference found between basins (Dunn's post hoc test result $<0.05$ ); - : no statistically significant differences found (Dunn's post hoc test result $>0.05$ )
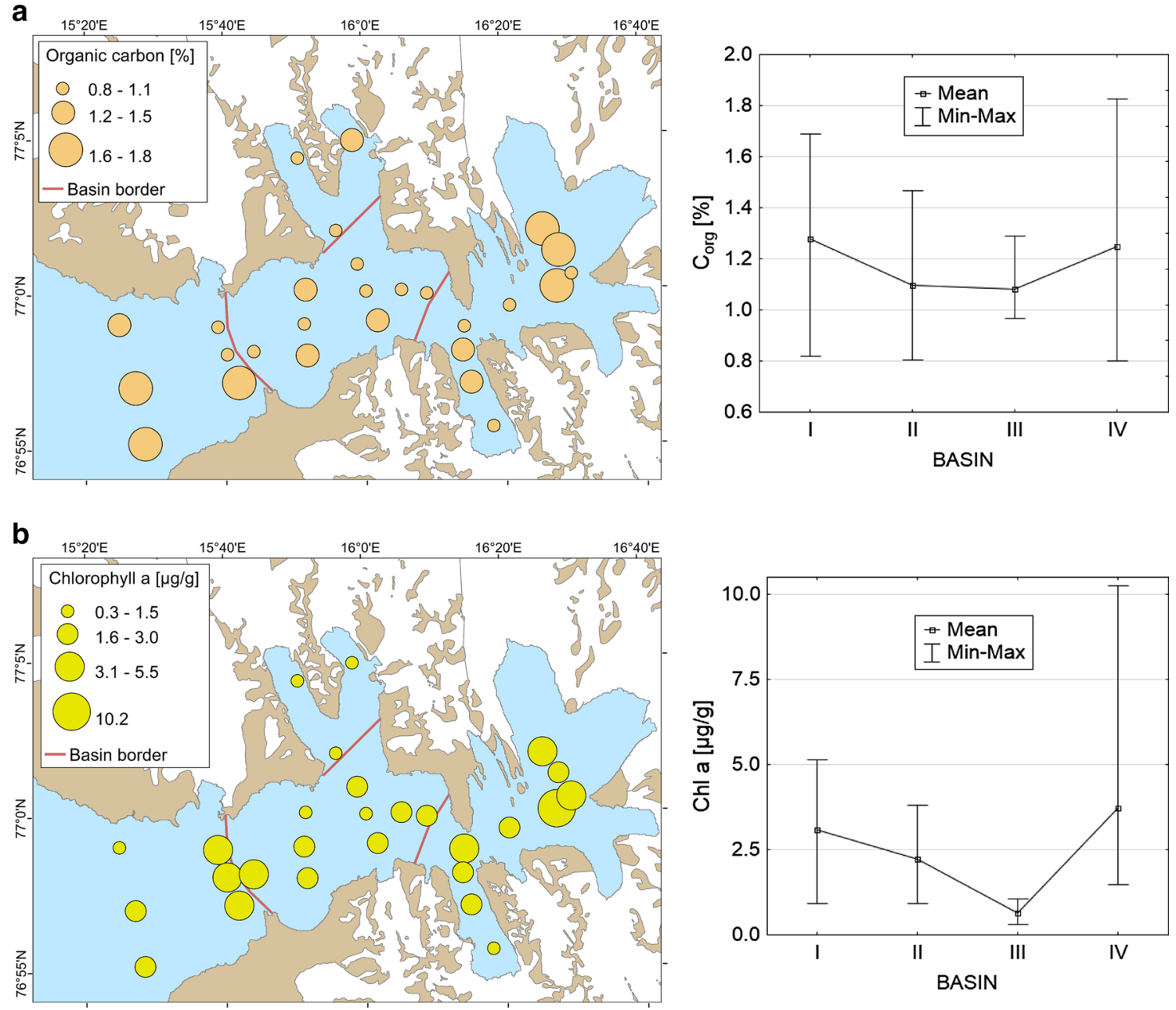

Fig. 2 Organic carbon content (a) and chlorophyll $a$ concentration (b) in Hornsund fjord sediments. Data collected in 2012

differences between Basin IV and two other basins: I and II $\left(\mathrm{H}_{(3, N=1056)}=24.67, p=0.000\right.$, Dunn's post hoc test: $p=0.000$ in both cases).
Variables that differed the most among fjord seabed were depth, bottom waters temperature and salinity. The highest variability in depth was documented in Basin II 

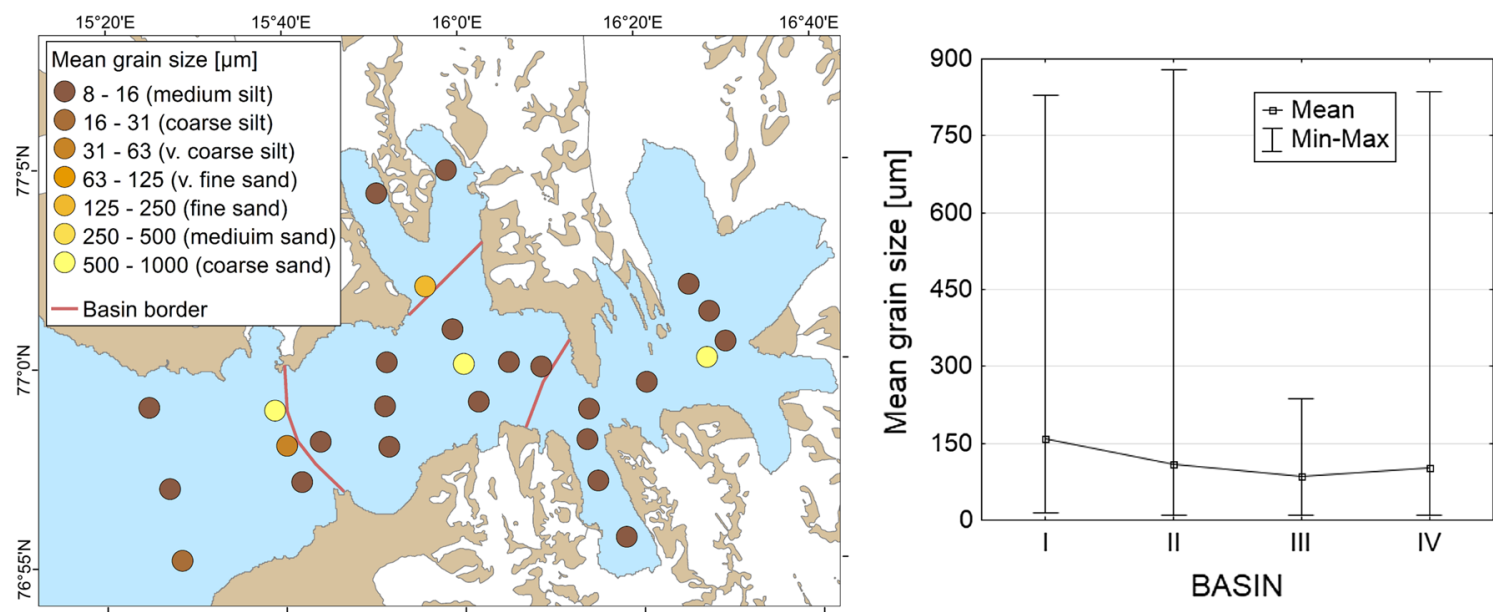

Fig. 3 Distribution of sediment types in Hornsund fjord (categorized based on the Wentworth (1922) scale)
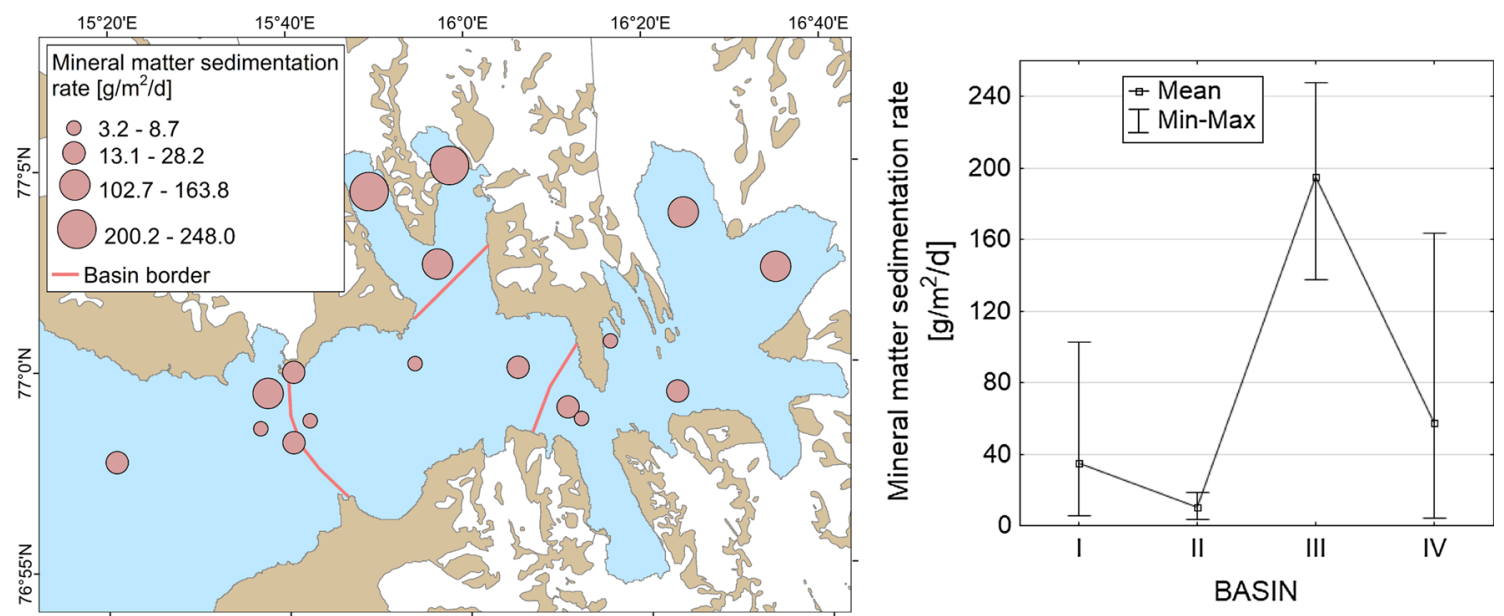

Fig. 4 Data on mineral matter sedimentation rates collected in Hornsund fjord in 2012-2013

(Fig. 5b). Only in this area all the distinguished classes, including the deepest one (200-260 m), were observed. A Kruskal-Wallis test confirmed differences between fjord basis $\left(\mathrm{H}_{(3, N=1056)}=83.90, p=0.000\right)$. Post hoc tests illustrated that sites were statistically similar in only one case: Basins III and IV (Dunn's test, $p=0.144$ ). The same situation was noted for near-bottom water temperature. Post hoc testing revealed significant differences between all basins except for Basins III and IV $\left(\mathrm{H}_{(3, N=201)}=123.80, p=0.000\right.$, Dunn's test: $\left.p=1.000\right)$ where the lowest mean values were observed with the minimum below $0{ }^{\circ} \mathrm{C}$ (Fig. 6a). With regard to near-bottom water salinity, post hoc tests illustrated that sites were statistically similar for Basins III and IV $(p=0.861)$ but also Basins I and II $\left(p=0.063 ; \mathrm{H}_{(3, N=201)}=84.86\right.$, $p=0.000)$. The later presented higher mean values of salinity. In general, lower values were observed towards the inner part of the fjord and at the glacier fronts (Fig. 6b).

Long-term measurements of near-bottom water temperature and salinity revealed variability among both basins and years. Time scale shows distinct annual episodes of warming $(2002,2006)$ and cooling (2010-2011) of the outer fjord basins (I and II), while innermost basin (IV) presents steady warming with a peak at the end of observation period (Fig. 7a). In case of mean salinity values, trend of decrease with time was observed in each basin (Fig. 7b).

Oxygen concentration and saturation measured at two monitoring sites confirmed good aerobic condition in Hornsund fjord. Both measures showed high levels of oxygen in near-bottom waters. Oxygen concentration and saturation at a station located in Basin I valued $12.5 \mathrm{mg} \mathrm{l}^{-1}$ and $118 \%$, respectively. Slightly lower values were noted in Basin II with concentration at level $9.5 \mathrm{mg}^{-1}$ and saturation of $77.6 \%$. 

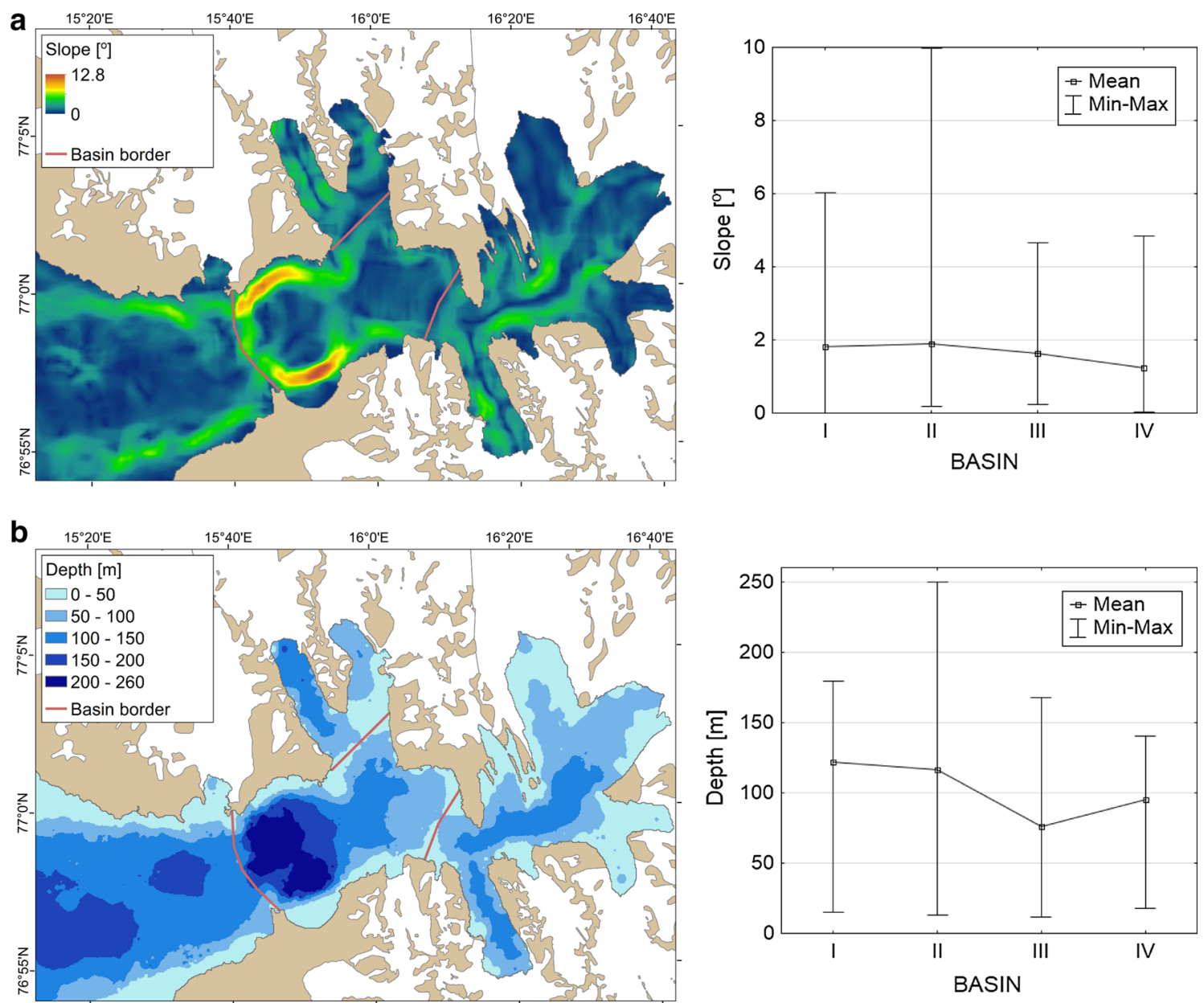

Fig. 5 Seabed slope (a) and depth (b) of Hornsund fjord

The simplified map of uniform environmental conditions indicated diversity of the Hornsund fjord seabed soft bottom habitats (Fig. 8). Although clear environmental barriers were not detected, graph illustrated division into following zones: from shelf to central basin and in the most inner basins of the fjord. A discontinuity of environmental conditions was observed between north and south glacial bays of the fjord.

\section{Discussion}

\section{Trophic conditions}

Sediment properties like grain size are known to directly influence meio- and macrofaunal density and diversity (Gray 2002). Sediments in the Hornsund fjord were quite homogenous in terms of granulometric characteristics. In general, the fine fraction of sediment dominated throughout the fjord. However, single patches of coarse sediment occurred, especially at the fjord mouth. In general, a decreasing trend in mean grain size values occurred towards the inner basins. This could suggest good trophic conditions in those areas. According to the literature, small particles serve as a better substrate for microorganisms that decompose organic matter and create better settlement conditions for benthic fauna with readily available organic carbon (Gray 2002; McArthur et al. 2010). Thus, muddy sediments together with high organic matter content are important factors that control distribution and positively affect macrozoobenthos communities (Denisenko et al. 2003). However, benthic richness in inner glacial fjord bays is rather low (Görlich et al. 1987; Sejr et al. 2000; Renaud et al. 2007). The same pattern is found in the Hornsund fjord (Wlodarska-Kowalczuk et al. 2005; Włodarska-Kowalczuk and Węsławski 2008; WłodarskaKowalczuk et al. 2013). This state may be attributed to high sedimentation rate of glacial material.

Intensive sedimentation of mineral matter in glacial fjords is known to cause not only sediment instability (Syvitski et al. 1987; Wlodarska-Kowalczuk et al. 2005), but also affects organic matter availability (Görlich et al. 

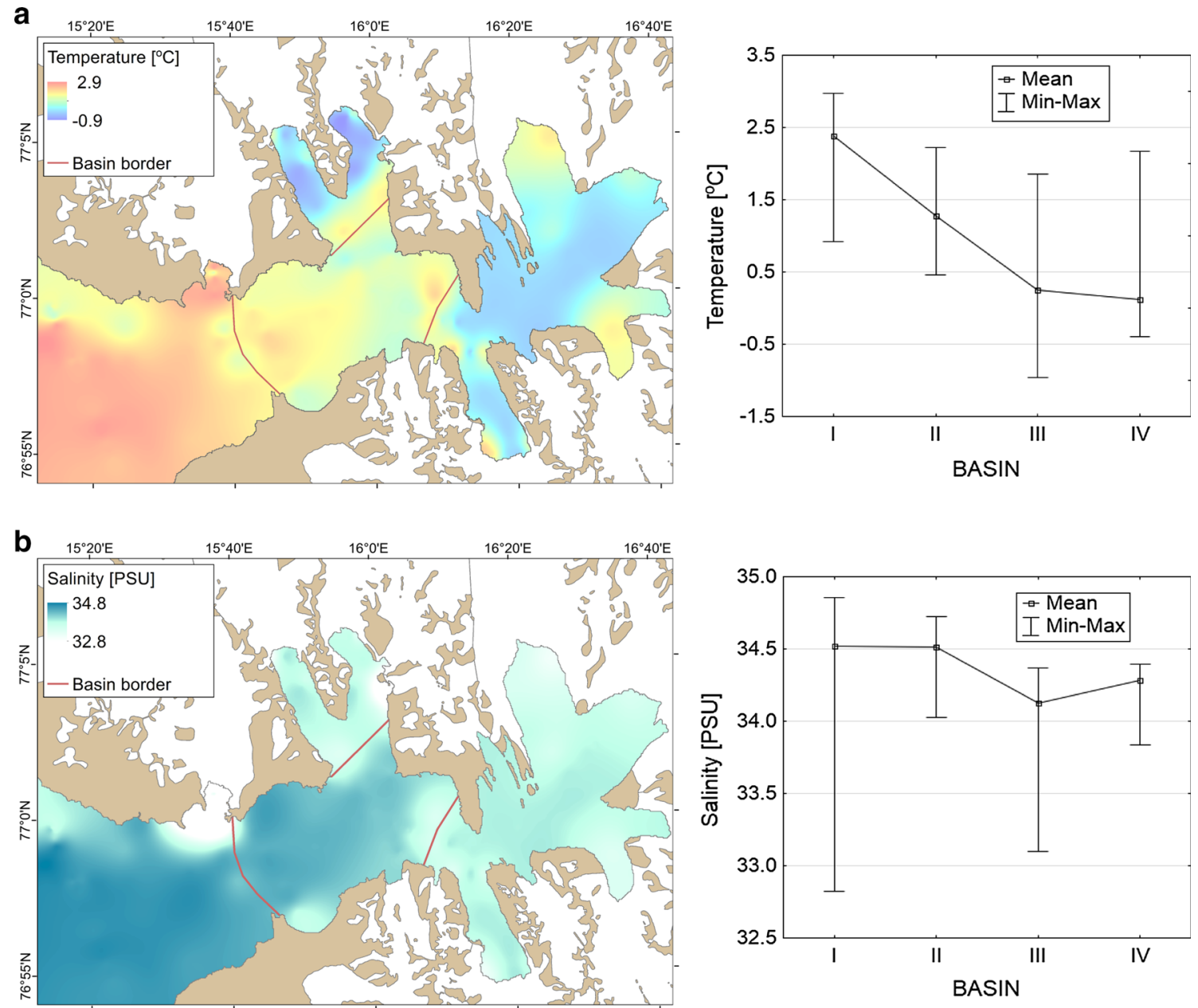

Fig. 6 Near-bottom temperature (a) and salinity (b) of Hornsund fjord waters in 2012

1987; Włodarska-Kowalczuk et al. 2013). The glacier proximal basins are usually reported as exposed for the highest sedimentation rates (Pearson 1980; Görlich et al. 1987), and thus it is expected that organic matter loads will be diluted in the mineral suspensions, what makes this place oligotrophic for benthic fauna (Włodarska-Kowalczuk et al. 1998). Previous research concerning organic matter availability in glacial fjords has documented a strong gradient diminishing toward inner basins (Görlich et al. 1987; Wlodarska-Kowalczuk and Pearson 2004). To our surprise no such trend was detected in our results. Our data indicated rather homogenous trophic condition in Hornsund fjord. We believe it might be attributed to extensive glacial retreat toward land that weakened the influence of glaciers on adjacent basins and entire fjord area. Stewart (1991) suggests that low sedimentation rates in the Arctic are related to glaciers retreat and increased sediment trapping in recently extended glacial fjords. According to recent literature, the majority of the suspended sediment is deposited in the very vicinity of the glacier fronts. Szczuciński and Zajączkowski (2012) noted that most of the sediments from the buoyant brackish plumes settle within $2-3 \mathrm{~km}$ from the glacier fronts. This can be seen in our results in Fig. 4 where decrease in sedimentation rates occurred towards the centre of Brepollen (Basin IV) and in general towards fjord centre. Table 2 additionally highlights the drop of average mineral suspension load in fjord center over the last 30 years. In general, organic matter content in sediments of Hornsund fjord decreased in comparison with archival data. This drop may suggest that more energy is utilized in the water column due to a weaker pelagic-benthic coupling (Petersen 1984; Węsławski et al. 2009).

The active tidal glacier fronts in Hornsund affect fjord not only by providing suspended sediments but also freshwater. The hydrographic phenomena connected with this coast form were presented in older works like Greisman (1979) as well as in new literature (Lydersen et al. 2014). Glaciers are modifying rather narrow zone near their fronts and that modification is of great importance for the 
Fig. 7 Long-term variability of near-bottom water temperature (a) and salinity (b) among Hornsund fjord basins. Data collected along fjord axis in 2001-2012
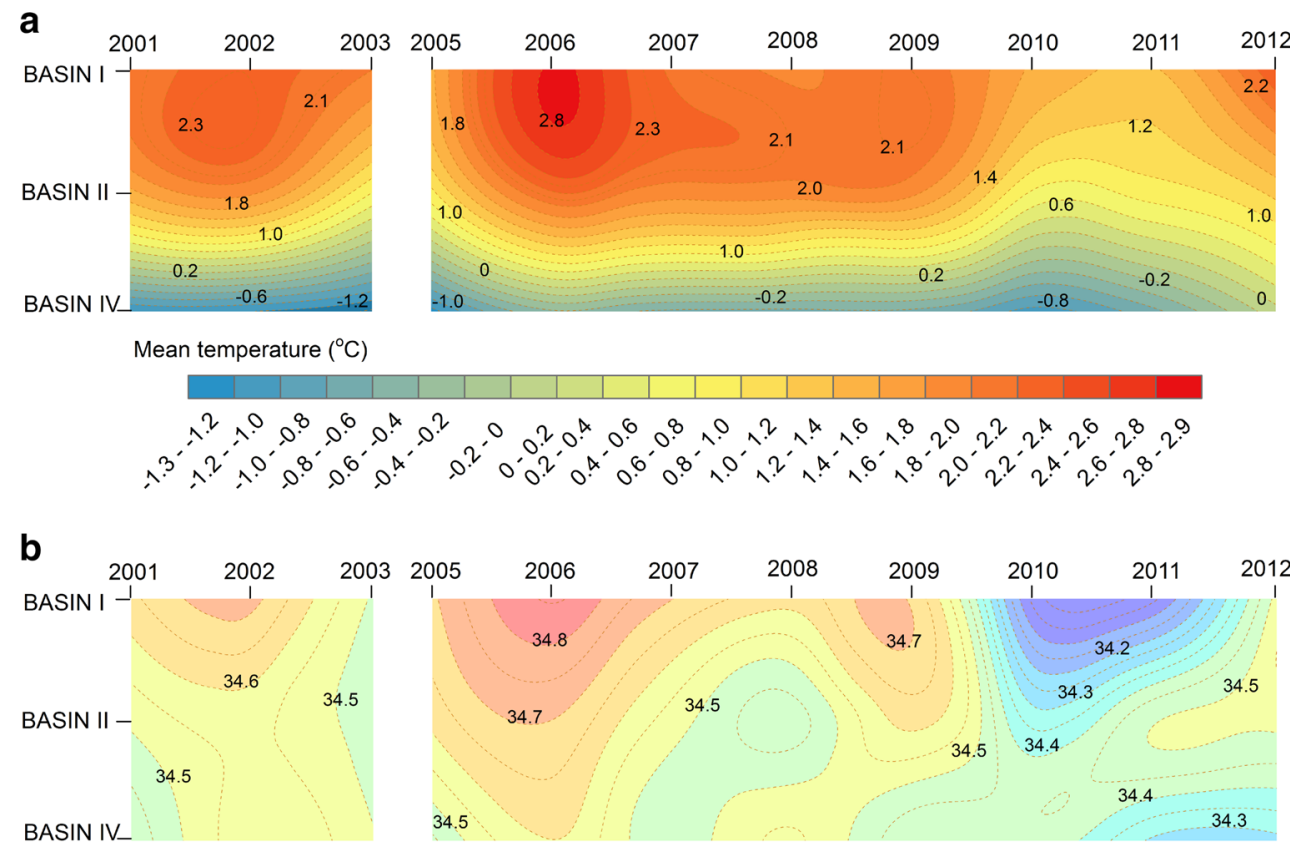

Mean salinity (PSU)

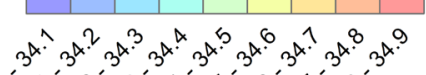

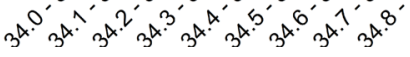

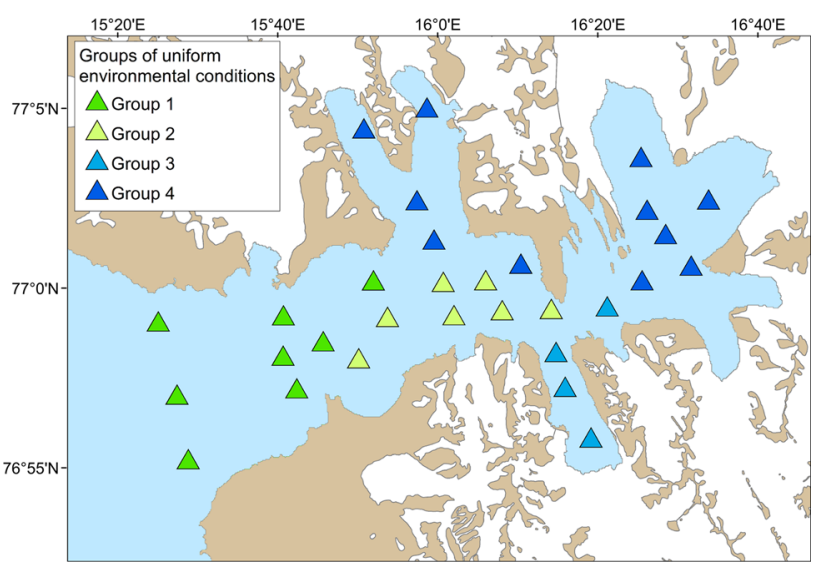

Fig. 8 Classes of uniform sea bed conditions (based on organic carbon content and chlorophyll $a$ concentration in sediments, mean grain size of sediments, mineral matter sedimentation rates, depth, near-bottom water temperature and salinity)

water column. Estuarine circulation and upwelling of more nutrient waters are observed that stimulate phytoplankton and zooplankton production (Węsławski and Legeżyńska 1998; Lydersen et al. 2014). It has already been proven that waters at the glacial fronts in Brepollen (Hornsund) are abundant with zooplankton (Trudnowska et al. 2014). Nonetheless, ongoing melting of the glaciers fronts has its consequences. Mass mortality of zooplankton communities is commonly linked with fresh water and mineral matter outflow from the glaciers (Węsławski and Legeżyńska 1998; Zajączkowski and Legeżyńska 2001). Likewise, phytoplankton mortalities have been attributed to direct salinity shock or limited light levels in the high turbid waters (Wiktor et al. 1998). That phenomenon may agree with our findings. The high mean values of $\mathrm{C}_{\text {org }}$ content and Chl $a$ concentration in the sediments observed in the most inner basin of the fjord may be explained by enhanced sinking of plankton associated with glacial activity. The fresh water transport from glaciers in Hornsund is assumed as about $1 \mathrm{~km}^{3}$ year ${ }^{-1}$, yet it appears in the surface waters only, and is highly seasonal (Węsławski et al. 1991). High food availability in the outer Basin I can be linked with a close proximity to warmer and more productive shelf waters like in an outer fjord basin in Pearson model (Pearson 1980). The high $\mathrm{C}_{\text {org }}$ content in sediments observed in our studies agrees with recent findings reported by Smith et al. (2015). They have compiled data on $\mathrm{C}_{\text {org }}$ content from nearly all fjord systems across the globe and shown that fjords are one of the major hotspots for organic carbon burial. The data obtained for Burgerbukta bay (Basin III) indicated poor trophic conditions in contrast to Brepollen (Basin IV). It appears that glaciers in Basin III are more active and intensive sedimentation rates dilutes organic material on the seabed.

For our assessment of benthic biota in Hornsund, we may conclude that nowadays glaciers are modifying rather 
Table 2 Summary of the environmental changes observed in benthic biotope in Hornsund fjord during last 30 years-compilation of data from cited literature and present results

\begin{tabular}{|c|c|c|}
\hline Factor & 1975-1985 & 2010-2012 \\
\hline Organic carbon in sediment & $\begin{array}{l}2.5-4 \% \text {, drop from open to inner part (Görlich } \\
\text { et al. 1987) }\end{array}$ & $0.8-1.8 \%$, even distribution \\
\hline $\begin{array}{l}\text { Average mineral suspensions load in surface } \\
\text { waters }\end{array}$ & $\begin{array}{l}\text { Central basin: } \\
15-20 \mathrm{mg} \mathrm{dm}^{-3} \text { (Görlich et al. 1987) } \\
\text { Outer basin (Isbjornhamna): } \\
65 \mathrm{mg} \mathrm{dm}^{-3} \text { (Görlich et al. 1987) }\end{array}$ & $\begin{array}{l}\text { Central basin: } \\
0.1-13 \mathrm{mg} \mathrm{dm}^{-3} \text { (IO PAS archive } \\
\text { 2013) } \\
\text { Outer basin (Isbjornhamna): } \\
146 \mathrm{mg} \mathrm{dm}^{-3} \text { (Zajączkowski } \\
\text { unpublished data) }\end{array}$ \\
\hline Seabed topography & $\begin{array}{l}\text { Ice scours from grounded icebergs, numerous } \\
\text { drop stones }\end{array}$ & No large icebergs, less dripstones \\
\hline Bathymetry & Deep bays near tidal glaciers & $\begin{array}{l}\text { Retreating tidal glaciers over shallow } \\
\text { bays }\end{array}$ \\
\hline $\begin{array}{l}\text { Minimal near-bottom temperature in summer at } \\
100 \mathrm{~m} \text { depth }\end{array}$ & $\begin{array}{l}\text { Central basin: } \\
-0.4{ }^{\circ} \mathrm{C} \text { (Urbański et al. 1980) } \\
\text { Inner basin (Brepollen): } \\
-1.9^{\circ} \mathrm{C} \text { (Urbański et al. 1980) }\end{array}$ & $\begin{array}{l}\text { Central basin: } \\
0.3^{\circ} \mathrm{C} \\
\text { Inner basin (Brepollen): } \\
-1.3{ }^{\circ} \mathrm{C}\end{array}$ \\
\hline $\begin{array}{l}\text { Maximal near-bottom temperature in summer at } \\
100 \mathrm{~m} \text { depth }\end{array}$ & $\begin{array}{l}\text { Central basin: } \\
0.5^{\circ} \mathrm{C} \text { (Urbański et al. 1980) } \\
\text { Inner basin (Brepollen): } \\
-1.9^{\circ} \mathrm{C} \text { (Urbański et al. 1980) }\end{array}$ & $\begin{array}{l}\text { Central basin: } \\
1.1^{\circ} \mathrm{C} \\
\text { Inner basin (Brepollen): } \\
-0.1{ }^{\circ} \mathrm{C}\end{array}$ \\
\hline $\begin{array}{l}\text { Maximal near-bottom salinity in summer at } 100 \mathrm{~m} \\
\text { depth }\end{array}$ & $\begin{array}{l}\text { Central basin: } \\
\text { 34.4 PSU (Urbański et al. 1980) } \\
\text { Inner basin (Brepollen): } \\
\text { 34.9 PSU (Urbański et al. 1980) }\end{array}$ & $\begin{array}{l}\text { Central basin: } \\
\text { 34.6 PSU } \\
\text { Inner basin (Brepollen): } \\
\text { 34.7 PSU }\end{array}$ \\
\hline
\end{tabular}

narrow zone near their fronts and that modification is of great importance for the water column (estuarine circulation, plankton concentration and mortality, upwelling-see Węsławski and Legeżyńska 1998; Lydersen et al. 2014) and seabed biota (more stable sediment, better conditions for reproduction and foraging due to lower sedimentation rates).

\section{Topography and hydrography}

Bathymetry may seem to be the most stable feature of the fjord, yet, in the case of the glacier movement (nearly $172 \mathrm{~km}^{2}$ in Hornsund in the last 100 years-Błaszczyk et al. 2009, 2013) it has changed over the years. Glacier fronts that were at the depth of $100 \mathrm{~m}$ in Brepollen are now at 40-50 m depth, and new extensive shallows appeared (Moskalik et al. 2013). Increase in newly exposed sea bed and change in fjords bathymetry are reported as typical for other Arctic locations like Alaska, Greenland and Svalbard in general (ACIA 2005; Weslawski et al. 2010). Boulton (1986) observed that both retreat and advance (surge) of glaciers produce marked changes to the sea bed. Forms of the seabed have most likely changed in the last 20 years, as the size of icebergs calving from the glaciers diminished, and shallower draft leaves no tracks on the seabed. This somewhat speculative conclusion is based on the reports from wintering in 1982-1984 (Görlich and Stepko 1992) and personal observations compared with reports from the last ten years. Our data showed that depth differed significantly throughout the fjord. As reported by McArthur et al. (2010), habitat heterogeneity can interrupt predator-prey relationships, thus impede the dominance of certain species. Despite that, newly exposed shallows may potentially serve as new habitats for benthic fauna.

Slope is a geomorphological feature that is of great ecological value. It describes the complexity of the seabed that is mirrored in transport and deposition of sediment, habitat structure, foraging patterns or macrofauna composition (McArthur et al. 2010). In our study, both patches of flat areas with low complexity as well as steep slope (especially along the coastline) were observed; however, when compared to Kongsfjorden, Hornsund is more homogenous (Pardus et al. unpublished data). The steepness of the fjord shows where the decaying algae rolling 
from the shallows may accumulate. This is important, as the increased production and spread of macrophytes was reported in the area (Weslawski et al. 2010). Hornsund is rather shallow and U-shaped, when compared to the deep and V-shaped Kongsfjord profile (http://www.iopan.gda.pl/ projects/Visual/index.html) and glacier retreat provides new sites of different morphology that may enhance the organic matter accumulation (Moskalik et al. 2013).

Although cold fjords are known to be well oxygenated through seasonal vertical mixing (Freeland et al. 1980; Syvitski et al. 1987), the increasing temperature and enhanced organic matter transport to the seabed, combined with restricted water exchange in isolated inner basins may create locally and seasonally anaerobic conditions in the seabed. Recent data from Kotwicki et al. (unpublished data) show the oxygenation of only upper $1 \mathrm{~cm}$ of sediment in Hornsund as effect of low bioturbidity and organic matter load, see also Wlodarska-Kowalczuk et al. (2005). Nevertheless, our monitoring measurements of oxygen concentration and saturation in near-bottom waters of Hornsund fjord indicated good aerobic conditions. Both parameters showed high values, irrespective of sampling location. Moreover, saturation levels did not changed much during the last 30 years. Values measured at the exact sampling stations by Urbański et al. (1980) also indicated a good aerobic state with saturation levels of 72 and $85 \%$ in Basins I and II, respectively. Similarly, extensive studies conducted by Jørgensen et al. (2005) did not present anoxic microenvironments in sediment, with average oxygen penetration to the sediment depth of 6-8 $\mathrm{mm}$ in Svalbard coastal waters. It appears that Hornsund fjord is stable with regard to aerobic conditions.

On the contrary, temperature and salinity of near-bottom waters varied interannually as well as between fjord basins. Multi-year oscillations observed especially at the fjord entrance suggest strong influence of shelf waters. These conclusions agree with the latest findings of increased inflow of warmer and more saline Atlantic water towards west Spitsbergen fjords (Pavlov et al. 2013). Pavlov et al. (2013) has additionally noted that Atlantic Water influence may be more visible in the bottom layer of Spitsbergen fjords than in the sub-surface layers that depend more on atmospheric forcing. Still, this Atlantic fluxes are believed to be limited only to outer and central basins of the fjords (Urbański et al. 1980; Swerpel 1985; Włodarska-Kowalczuk et al. 2013). Inner glacial basins, on the contrary, are believed to be suitable refuge for Arctic taxa. Norwegian fjords are known to host cold-water species in the innermost basins, contrary to outer basins dominated by Atlantic, warmer species (Freeland et al. 1980). The same distribution of species may occur in the future in the fjords of European Arctic. Although an increase in near-bottom water temperature occurred over the last 30 years, the coldest water masses are still noted in the most inner basins of the Hornsund fjord. However, the amount of cold winter water is highly variable in recent years (Promińska et al. unpublished data).

In conclusion, we have documented data concerning environmental factors known to be important for distribution and persistence of benthic fauna. This is the first study to address such a numerous amount of physical parameters representing conditions prevailing at the bottom of the Hornsund fjord. As was summarised in Table 2, there is a tendency towards an evolution to "boreal fjord" according to the Pearson (1980) model. The observed changes can be extrapolated to produce scenarios for other cold water fjords that are exposed to the climate warming. New extensive shallows appeared, temperature increased and salinity decreased. There are changes in the amount and influence of suspended matter supply and turnover in organic matter distribution throughout the fjord. Our findings suggest that contrary to common opinion (Węsławski et al. 2011) glacial retreat is not leading to the constantly increased turbidity and sedimentation. Apparently this is the case of the first stage of the retreat, when the glacier drains rapidly and can both disturb the seabed in large area and release lots of sediment. As the glacier gets thinner, its front gets narrower and retreats to shallower areas, the sediment flux's range decreases. This needs to be confirmed in the future research. The drop in organic matter content may suggest that more energy is utilized in the water column due to a weaker pelagic-benthic coupling-a phenomenon attributed to subarctic versus arctic ecosystems (Petersen 1984; Węsławski et al. 2009).

It appears the Hornsund fjord is becoming homogenized with less diversification among individual basins; a similar observation was recorded in Kongsfjorden between 1998 and 2006 (Kędra et al. 2010b). With the use of statistical testing and GIS analysis, we have pointed out ares of homogeneous and heterogeneous conditions. Although clear environmental barriers were not detected, it seems that principal driving forces for the benthic organisms living conditions in Hornsund fjord are shelf waters and glaciers activity. We distinguished uniform zones at the fjord mouth, in the middle basin along fjord axis and in the most inner basins of the fjord. Multi-year temperature and salinity means shows the importance of external driving force (variable advection of shelf waters documented by Walczowski and Piechura 2006; Walczowski et al. 2012) for the benthic fauna living at the fjord mouth, while innermost basin, regarded as cold and very stable (Weslawski et al. 2010) shows steady change likely due to the lesser production of winter cooled water-already recorded in other Svalbard fjords (Svendsen et al. 2002). Since temperature and salinity seemed the least stable variables in the fjord, it can be expected that they will have the 
biggest influence on benthic fauna distribution and composition during ongoing changes. Already an increase in biomass and diversity of fauna is observed (Węsławski et al. 2011; Grzelak and Kotwicki unpublished data). Also the prolongation of the productive vegetation period is very likely (Piwosz et al. 2009). Further investigations are needed to verify exactly which physical drivers control species distribution. The next stage of our research will be performing Species Distribution Modelling that shall verify importance of various abiotic parameters for selected benthic species, map their distribution and point out potential refugia for species of Arctic origin.

Acknowledgments The research leading to these results has received funding from the National Center for Science in Krakow, Poland ("Cold water benthic fauna relicts in warmed up fjords-GIS approach"-2012/05/N/ST10/03856, “FACE2FACE"-2012/05/B/ ST10/01908, "GAME"-2012/04/A/NZ8/00661) and the PolishNorwegian Research Programme operated by the National Centre for Research and Development under the Norwegian Financial Mechanism 2009-2014 in the frame of Project Contract No. DZP/POLNOR/1876/2013. IO PAN in Sopot contributed to this study by providing ship time and manpower. Special thanks to Dr. Marek Zajaczkowski from the Marine Ecology Department IO PAN for providing data on suspension and sedimentation. We thank Emilia Trudnowska from the Marine Ecology Department IO PAN for additional data on bottom water temperature and salinity. We wish to thank Dr. Piotr Kowalczuk from the Department of Marine Physics IO PAN for the access to spectrofluorometer used for photosynthetic pigments content analyses. The authors declare that they have no conflict of interest.

Open Access This article is distributed under the terms of the Creative Commons Attribution 4.0 International License (http://crea tivecommons.org/licenses/by/4.0/), which permits unrestricted use, distribution, and reproduction in any medium, provided you give appropriate credit to the original author(s) and the source, provide a link to the Creative Commons license, and indicate if changes were made.

\section{References}

ACIA (2005) Arctic climate impact assessment. Cambridge University Press, Cambridge

Błaszczyk M, Jania JA, Hagen JO (2009) Tidewater glaciers of Svalbard: recent changes and estimates of calving fluxes. Pol Polar Res 30:85-142

Błaszczyk M, Jania JA, Kolondra L (2013) Fluctuations of tidewater glaciers in Hornsund Fjord (Southern Svalbard) since the beginning of the 20th century. Pol Polar Res 34:327-352. doi:10.2478/popore-2013-0024

Blott SJ, Pye K (2001) GRADISTAT: a grain size distribution and statistics package for the analysis of unconsolidated sediments. Earth Surf Proc Land 26:1237-1248. doi:10.1002/esp.261

Boulton GS (1986) Push Moraines and glacier-contact fans in marine and terrestrial environments. Sedimentology 33:667-698

Chang FY, Kao SJ, Liu KK (1991) Analysis of organic and carbonate carbon in sediments. Acta Oceanogr Taiwan 27:14-150

Cottier F, Tverberg V, Inall M, Svendsen H, Nilsen F, Griffiths C (2005) Water mass modification in an Arctic fjord through crossshelf exchange: the seasonal hydrography of Kongsfjorden,
Svalbard. J Geophys Res-Oceans 110:1-18. doi:10.1029/ 2004JC002757

Cottier FR, Nilsen F, Skogseth R et al (2010) Arctic fjords: a review of the oceanographic environment and dominant physical processes. Geol Soc Lond Spec Publ 344:35-50. doi:10.1144/ SP344.4

Dale JE, Aitken AE, Gilbert R, Risk MJ (1989) Macrofauna of Canadian arctic fjords. Mar Geol 85:331-358

Denisenko SG, Denisenko NV, Lehtonen KK, Andersin AB, Laine AO (2003) Macrozoobenthos of the Pechora Sea (SE Barents Sea): community structure and spatial distribution in relation to environmental conditions. Mar Ecol-Prog Ser 258:109-123. doi:10.3354/meps 258109

Dowdeswell JA (1995) Glaciers in the High Arctic and recent environmental change. Philos Trans R Soc 352A:321-334

Evans CA, O'Reilly JE (1983) A handbook for the measurement of chlorophyll-a in netplankton and nannoplankton. BIOMASS Sci Ser 9:1-44

Evans CA, O'Reilly JE, Thomas JP (1987) A handbook for the measurement of chlorophyll-a and primary productivity. BIOMASS Sci Ser 8:1-114

Freeland HJ, Farmer DM, Levings CD (1980) Fjord oceanography. Plenum Press, New York

Glover AG, Gooday AJ, Bailey DM, Billett DSM, Chevaldonne P, Colaco A, Copley J, Cuvelier D, Desbruyeres D, Kalogeropoulou V, Klages M, Lampadariou N, Lejeusne C, Mestre NC, Paterson GLJ, Perez T, Ruhl H, Sarrazin J, Soltwedel T, Soto EH, Thatje S, Tselepides A, Van Gaever S, Vanreusel A (2010) Temporal change in deep-sea benthic ecosystems: a review of the evidence from recent time-studies. In: Lesser $M$ (ed) Advances in marine biology, vol 58, 1st edn. Academic Press, UK, pp 1-95. doi:10.1016/s0065-2881(10)58001-5

Görlich K, Stepko W (1992) Hydrological phenomena related to seaice cover formation and presence in Hornsund, Spitsbergen. In: Opaliński KW, Klekowski RZ (eds) Landscape, life world and man in High Arctic. Institute of Ecology PAS Publishing Office, Warsaw, pp 255-269

Görlich K, Węsławski JM, Zajączkowski M (1987) Suspensions settling effect on macrobenthos biomass distribution in the Hornsund fjord, Spitsbergen. Polar Res 5:175-192

Gray JS (2002) Species richness of marine soft sediments. Mar EcolProg Ser 244:285-297. doi:10.3354/meps244285

Greisman P (1979) On upwelling driven by the melt of ice shelves and tidewater glaciers. Deep-Sea Res 26A:1051-1065

Hagen JO, Melvold K, Pinglot F, Dowdeswell JA (2003) On the net mass balance of the glaciers and ice caps in Svalbard, Norwegian Arctic. Arct Antarct Alp Res 35(2):264-270

Hedges JI, Stern JH (1984) Carbon and nitrogen determinations of carbonate-containing solids. Limnol Oceanogr 29:657-663

Hoelemann JA, Kirillov S, Klagge T, Novikhin A, Kassens H, Timokhov L (2011) Near-bottom water warming in the Laptev Sea in response to atmospheric and sea-ice conditions in 2007. Polar Res. doi:10.3402/polar.v30i0.6425

Hop H, Pearson T, Hegseth EN, Kovacs K, Wiencke C, Kwaśniewski S, Eiane K, Mehlum F, Gulliksen Włodarska-Kowalczuk M, Lydersen C, Weslawski JM, Cochrane S, Gabrielsen GW, Leakey R, Lonne OJ, Zajączkowski M, Falk-Petersen S, Kendall M, Wangberg SA, Bischof K, Voronkov AY, Kovaltchuk Wiktor J, Plterman M, Di Prisco G, Estoppey A, Papucci C, Gerland S, Lippert H (2002) The marine ecosystem of Kongsfjorden, Svalbard. Polar Res 21:167-208. doi:10.1111/j.1751-8369.2002.tb00073.x

Jørgensen BB, Glud RN, Holby O (2005) Oxygen distribution and bioirrigation in Arctic fjord sediments (Svalbard, Barents Sea). Mar Ecol-Prog Ser 292:85-95

Kędra M, Gromisz S, Jaskula R, Legeżyńska J, Maciejewska B, Malec E, Opanowski A, Ostrowska K, Włodarska-Kowalczuk 
M, Węsławski JM (2010a) Soft bottom macrofauna of an All Taxa Biodiversity Site: Hornsund $\left(77^{\circ} \mathrm{N}\right.$, Svalbard). Pol Polar Res 31:309-326. doi:10.2478/v10183.010.0008.y

Kędra M, Włodarska-Kowalczuk M, Węsławski JM (2010b) Decadal change in macrobenthic soft-bottom community structure in a high Arctic fjord (Kongsfjorden, Svalbard). Polar Biol 33:1-11. doi:10.1007/s00300-009-0679-1

Koerner RM, Fisher DA (2002) Ice-core evidence for widespread Arctic glacier retreat in the Last Interglacial and the early Holocene. Ann Glaciol 35:19-24

Kröncke I (1995) Long-term changes in North Sea benthos. Senck Marit 26:73-80

Łącka M, Zajączkowski M (2015) Does the recent pool of benthic foraminiferal tests in fjordic surface sediments reflect interannual environmental changes? The resolution limit of the foraminiferal record. Ann Soc Geol Pol. doi:10.14241/asgp. 2015.019

Lydersen C, Assmy P, Falk-Petersen S, Kohler J, Kovacs Kit M, Reigstad M, Steen H, Strøm H, Sundfjord A, Varpe $\varnothing$, Walczowski W, Weslawski JM, Zajaczkowski M (2014) The importance of tidewater glaciers for marine mammals and seabirds in Svalbard, Norway. J Mar Syst 129:452-471

McArthur MA, Brooke BP, Przeslawski R, Ryan DA, Lucieer VL, Nichol S, McCallum AW, Mellin C, Cresswell ID, Radke LC (2010) On the use of abiotic surrogates to describe marine benthic biodiversity. Estuar Coast Shelf S 88:21-32. doi:10. 1016/j.ecss.2010.03.003

Moskalik M, Grabowiecki P, Tęgowski J, Żulichowska M (2013) Bathymetry and geographical regionalization of Brepollen (Hornsund, Spitsbergen) based on bathymetric profiles interpolations. Pol Polar Res 34:1-22. doi:10.2478/popore-2013-0001

Pavlov AK, Tverberg V, Ivanov BV, Nilsen F, Falk-Petersen S, Granskog MA (2013) Warming of Atlantic Water in two west Spitsbergen fjords over the last century (1912-2009). Polar Res. doi:10.3402/polar.v32i0.11206

Pearson TH (1980) The macrobenthos of fjords. In: Freeland HJ, Farmer DM, Levings CD (eds) Fjord oceanography. Plenum Press, New York, pp 569-603

Petersen GH (1984) Energy flow in comparable aquatic ecosystems from different climatic zones. Rapp p-v réun - Cons int explor mer 183:119-125

Piechura J, Beszczyńska-Moller A, Osiński R (2001) Volume, heat and salt transport by the West Spitsbergen Current. Polar Res 20:233-240. doi:10.1111/j.1751-8369.2001.tb00061.x

Piwosz K, Walkusz W, Hapter R, Wieczorek P, Hop H, Wiktor J (2009) Comparison of productivity and phytoplankton in a warm (Kongsfjorden) and a cold (Hornsund) Spitsbergen fjord in midsummer 2002. Polar Biol 32:549-559. doi:10.1007/s00300-0080549-2

Powell RD, Molnia BF (1989) Glacimarine sedimentary processes, facies and morphology of the south-southeast Alaska shelf and fjords. Mar Geol 85:359-390. doi:10.1016/0025-3227(89)901606

Renaud PE, Włodarska-Kowalczuk M, Trannum H, Holte B, Węsławski JM, Cochrane S, Dahle S, Gulliksen B (2007) Multidecadal stability of benthic community structure in a highArctic glacial fjord (van Mijenfjord, Spitsbergen). Polar Biol 30:295-305. doi:10.1007/s00300-006-0183-9

Renaud PE, Carroll ML, Ambrose WG Jr (2008) Effects of global warming on Arctic sea-floor communities and its consequences for higher trophic levels. In: Duarte CM (ed) Impacts of global warming on polar ecosystems. Fundación BBVA, Madrid, pp 139-175

Rudowski S, Marsz A (1996) Cechy rzeźby dna i pokrywy osadowe we współcześnie kształtujących się fiordach na przykładzie Hornsundu (Spitsbergen) i Zatoki Admiralicji (Antarktyka
Zachodnia). In: Styszyńska A (ed) Zagadnienia genezy i geomorfologii współcześnie rozwijających się fiordów strefy polarnej. Wydawnictwo Uczelniane WSM, Gdynia, pp 39-81

Rysgaard S, Glud RN (2007) Carbon cycling in Arctic marine ecosystems: case study Young Sound. Meddelelser om Grønland, Copenhagen

Schmid M, Piepenburg D (1993) The benthos zonation in Disco Fjord. West Greenland, Meddelelser om Grønland, Copenhagen

Sejr MK, Jensen KT, Rysgaard S (2000) Macrozoobenthic community structure in a high-arctic East Greenland fjord. Polar Biol 23:792-801. doi:10.1007/s003000000154

Siwecki R, Swerpel S (1979) Badania oceanograficzne w fiordzie Hornsund w latach 1974-1975. In: Zesz nauk Wydz Biologii i Nauk o Ziemi Uniwersytetu Gdańskiego - Oceanografia 6. Wydawn. Uczelniane Uniwersytetu Gdańskiego, Gdańsk, pp 46-58

Smith RW, Bianchi TS, Allison M et al (2015) High rates of organic carbon burial in fjord sediments globally. Nat Geosci 8:450-453. doi:10.1038/ngeo2421

Snelgrove PVR (2001) Diversity of Marine Species. In: Steele JH, Thorpe SA, Turekian KK (eds) Encyclopedia of ocean sciences. Academic Press, San Diego, pp 748-757

Stewart TG (1991) Glacial marine sedimentation from tidewater glaciers in the Canadian High Arctic. In: Anderson JB, Ashley GM (eds) Glacial marine sedimentation: paleoclimatic significance. Geological Society of America, Special Papers vol 261, Boulder Colorado, pp 95-106

Svendsen H, Beszczynska-Moller A, Hagen JO, Lefauconnier B, Tverberg V, Gerland S, Orbaek JB, Bischof K, Papucci C, Zajaczkowski M, Azzolini R, Bruland O, Wiencke C, Winther JG, Dallmann W (2002) The physical environment of Kongsfjorden-Krossfjorden, an Arctic fjord system in Svalbard. Polar Res 21:133-166. doi:10.1111/j.1751-8369.2002.tb00072.x

Swerpel S (1985) The Hornsund fjord-water masses. Pol Polar Res 6:475-496

Swerpel S, Węsławski JM (1989) Polish marine ecological work on Spitsbergen. Rapp p-v réun - Cons int explor mer 188:177-179

Syvitski JPM, Burrell DC, Skei JM (1987) Fjords. Processes and products. Springer, New York

Szczuciński W, Zajączkowski M (2012) Factors controlling downward fluxes of particulate matter in glacier-contact and nonglacier contact settings in a subpolar fjord (Billefjorden, Svalbard). In: Li M, Sherwood C, Hill P (eds) Sediments, morphology and sedimentary processes on continental shelves, IAS Special Publication. Wiley-Blackwell Publishing, Hoboken, pp 369-386

Trudnowska E, Basedow SL, Blachowiak-Samolyk K (2014) Midsummer mesozooplankton biomass, its size distribution, and estimated production within a glacial Arctic fjord (Hornsund, Svalbard). J Mar Syst 137:55-66. doi:10.1016/j.jmarsys.2014.04.010

Urbański J, Neugenbauer E, Spacjer R, Falkowska L (1980) Physicochemical characteristic of the waters of Hornsund Fjord on south-west Spitsbergen (Svalbard Archipelago) in the summer season 1979. Pol Polar Res 1:43-52

Walczowski W, Piechura J (2006) New evidence of warming propagating toward the Arctic Ocean. Geophys Res Lett. doi:10.1029/2006gl025872

Walczowski W, Piechura J, Goszczko I, Wieczorek P (2012) Changes in Atlantic water properties: an important factor in the European Arctic marine climate. ICES J Mar Sci 69(5):864-869. doi:10. 1093/icesjms/fss068

Warwick RM (1993) Environmenatl-impact studies on marine communities-pragmatical considerations. Aust $\mathrm{J}$ Ecol 18:63-80. doi:10.1111/j.1442-9993.1993.tb00435.x

Wentworth CK (1922) A scale of grade and class terms for clastic sediments. J Geol 30:377-392 
Węsławski JM, Legeżyńska J (1998) Glaciers caused zooplankton mortality? J Plankton Res 20:1233-1240

Weslawski JM, Wiktor J Jr, Kotwicki L (2010) Increase in biodiversity in the Arctic rocky littoral, Sorkappland, Svalbard after 20 years of climate warming. Mar Biodiv 40:123-130

Węsławski JM, Jankowski A, Kwaśniewski S, Swerpel S, Ryg M (1991) Summer hydrology and zooplankton in two Svalbard fjords. Pol Polar Res 12:445-460

Węsławski JM, Kwaśniewski S, Stempniewicz L (2009) Warming in the Arctic may result in the negative effects of increased biodiversity. Polarforschung 78:105-108

Węsławski JM, Kendall MA, Włodarska-Kowalczuk M, Iken K, Kędra M, Legezynska J, Sejr M (2011) Climate change effects on Arctic fjord and coastal macrobenthic diversity-observations and predictions. Mar Biodiv 41:71-85

Wiktor J, Węsławski JM, Wieczorek P, Zajączkowski M, Okolodkov J (1998) Phytoplankton and suspensions in relation to the freshwater in Arctic coastal marine ecosystems. Pol Polar Res 19:215-230

Wlodarska-Kowalczuk M, Pearson TH (2004) Soft-bottom macrobenthic faunal associations and factors affecting species distributions in an Arctic glacial fjord (Kongsfjord, Spitsbergen). Polar Biol 27:155-167. doi:10.1007/s00300-003-0568-y
Włodarska-Kowalczuk M, Węsławski JM (2008) Mesoscale spatial structures of soft-bottom macrozoobenthos communities: effects of physical control and impoverishment. Mar Ecol-Prog Ser 356:215-224. doi:10.3354/meps07285

Wlodarska-Kowalczuk M, Pearson TH, Kendall MA (2005) Benthic response to chronic natural physical disturbance by glacial sedimentation in an Arctic fjord. Mar Ecol-Prog Ser 303:31-41. doi: $10.3354 /$ meps303031

Włodarska-Kowalczuk M, Węsławski JM, Kotwicki L (1998) Spitsbergen glacial bays macrobenthos-a comparative study. Polar Biol 20:66-73

Włodarska-Kowalczuk M, Renaud PE, Węsławski JM, Cochrane SKJ, Denisenko SG (2012) Species diversity, functional complexity and rarity in Arctic fjordic versus open shelf benthic systems. Mar Ecol-Prog Ser 463:73-87. doi:10.3354/meps09858

Włodarska-Kowalczuk M, Pawłowska J, Zajączkowski M (2013) Do foraminifera mirror diversity and distribution patterns of macrobenthic fauna in an Arctic glacial fjord? Mar Micropaleontol 103:30-39. doi:10.1016/j.marmicro.2013.07.002

Zajączkowski M, Legeżyńska J (2001) Estimation of zooplankton mortality caused by an Arctic glacier outflow. Oceanologia 43:341-351 